\title{
Accounting
}

homepage: www.GrowingScience.com/ac/ac.html

\section{The determinants of lending interest rates of Jordanian listed commercial banks}

\section{Ali Mustafa Al-Qudah ${ }^{a^{*}}$}

${ }^{a}$ Department of Finance and Business Economics, Faculty of Economics and Administrative Sciences, Al Al-Bayt University, Mafraq, Jordan

\begin{tabular}{l}
\hline C H R O N I C L E \\
\hline Article history: \\
Received: November 28, 2020 \\
Received in revised format: \\
December 282020 \\
Accepted: February 7, 2021 \\
Available online: \\
February 7, 2021 \\
\hline Keywords: \\
Lending interest rate \\
Commercial banks \\
Liquidity \\
Deposit rate
\end{tabular}

\section{Introduction}

The banking sector plays a major and fundamental role in economic growth. Since, it is the primary device for directing funds from depositors to borrowers, taking into account the redistribution of these funds to efficient and highly efficient economic activities (Andrew, 2004). It provides short, medium, and long-term loans, according to the desire of customers and the lending principles of banks, in order to enable borrowers to carry out their various economic activities that generate economic growth. Granting credit to individuals, investors, and the government are the main activities of the commercial banks. It must be taken into account that loans carry a degree of risk, which may affect the financial solvency, liquidity and profitability of banks. The lending capacity of the bank generally depends on the bank's capital, deposit, inflation, gross domestic product (GDP), liquidity, and credit policy issued by the central bank in the country and by the management of the commercial banks (CB) (Olusanya et al., 2012). The interest on loaned funds is the main source of income for (CB). Also, the interest rate on granted loans is one of the important matters that are taken into consideration when making a lending decision by (CB). Since interest is imposed by commercial banks on loans for profits, preserving the value of loaned funds, compensation for risks and payment of various operating expenses in addition to paying interest to depositors (Sheriff \& Amoako, 2014). The lending interest rate is defined as the interest that commercial banks charge when making loans to customers. From an economic perspective, the interest rate is the payment for services provided by the capital (Crowley, 2007). Keynes (1936) defined the interest rate as the reward for giving up liquidity for a specified period of time.

\footnotetext{
* Corresponding author.

E-mail address: alimqf@yahoo.com (A. M. Al-Qudah)
}

\begin{abstract}
This study aimed to examine the determinants of lending interest rates of 13 Jordanian commercial banks listed on the Amman Stock Exchange for the period 2011-2018. The factors include liquidity,
profitability (ROA), bank size, operating cost ratio, deposit interest rate and inflation rate. The fixed effects model was performed as suggested by Hausman test. The results of the fixed effects model show that ROA and bank size had negative significant impacts on lending interest rates. Liquidity a positive significant impact on lending interest rate of Jordanian commercial banks. Operating cost ratio also had a positive insignificant impact. Thus, the results indicate that ROA, bank size, deposit commercial banks. The study suggests that banks should use profitability and the size of the bank as tools to reduce the lending interest rate, as it is one of the factors that can cause a further decrease in the lending interest rates.
\end{abstract}

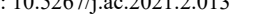


Commercial banks cannot impose very low lending interest rates because the income from interest will not be sufficient to cover the various operational and non-operational costs. Also, it cannot impose very high lending interest rates because it will lose the relationship with borrowers. Thus, the process of selecting appropriate lending interest rates is usually an important issue not only for (CB), but also for policy makers and people in general. The lending interest rate of (CB) is affected by many factors. According to classical theory, the interest rate is determined by the supply of saving and the demand for capital by the business sector (Friedman \& Kuttner, 1991; Rose, 2003). Rational expectation theory assumes that the best estimate of future interest rates is the current rate and changes in the interest rate resulting mainly from unexpected information or economic variables. Finally, the loanable funds theory assumes that the interest rate is a function of saving, investment, money supply, and the desire to hoard (Peng et al., 2002). The previous literature indicated that there are many variables that may affect lending interest rates (LIR) of commercial banks, including macroeconomic variables such as inflation, economic growth and exchange rate and macroeconomic variables such as profitability, non-performing loans, operating costs, interest paid to depositors, and other variables. The first motive for this study is that (LIR) play an important role in the daily economic life of countries, as they affect the ability of individuals and investors to borrow. The significant direction of the interest rate has a significant impact on investments in the economy. High interest rates negatively affect economic activity. As for low interest rates, they greatly contribute to revitalizing the economy. The second motive for this study is that the (LIR) in Jordan are high since the mean lending interest rate is (10.8\%) for the period of the study (2011-2018), this means that Jordanian commercial banks charge an average of $10.8 \%$ annual interest on loans and advances. the maximum and minimum are (15.6\%), (8.06\%) respectively. So these rates are greater than that of other Arab countries, especially the oil-rich countries, as well as with the rest of the world. This high (LIR) negatively affects the ability of individuals and investors to borrow, which in turn negatively affects the economic growth in Jordan. Especially in light of the conditions that the world went through, starting from the world financial crisis of 2008 and ending with the Corona pandemic 2020, in addition to the conditions of the Arab Spring that the Arab world went through, which left significant negative impacts on economic activity. The third motive is that the commercial banks are among the main contributors to economic growth by providing credit facilities to investors and the business sector. Also, loans are one of the main functions of commercial banks, so knowing the interest rate determinants will help (CB) to enhance their performance. The results of this study may also benefit policy makers, specialists, researchers and those interested in banking. It is worth mentioning that the banking sector in Jordan consists of 24 banks, including 16 Jordanian banks, 13 commercial banks and 3 Islamic banks, all of which are listed on the Amman Stock Exchange and 8 non-Jordanian banks, including 7 commercial banks and one Islamic bank. The Jordanian economy depends mainly on the banking sector. Which is the main financier for development in Jordan, since Banks constitute more than 95\% of the share of financing in Jordan, Credit facilities provided by banks constitute $87 \%$ of the GDP, which exceeds US\$ 44 billion. For all the above, this study aims to identify the determinants of lending interest rates of the 13 Jordanian commercial banks listed on the Amman Stock Exchange for the period of time 2011-2018. The remainder of the study is organized as follows. Section two presents literature review. Section three presents data and methodology. Section four presents empirical results and discussions. Section five presents conclusions and recommendations.

\section{Literature Review}

The previous studies that dealt with the determinants of the (LIR) for commercial banks have distributed the determinants into three groups, which are as follows: The first group of macroeconomic variables such as inflation, economic growth, and the exchange rate. The second group related to the banking sector, such as concentration and reserve requirements. The third group represents the bank's characteristics such as profitability, liquidity, bank size, non-performing loans, deposit interest rates and operating costs (Cihak, 2004; Georgievska et al., 2011). Moreover, the studies that dealt with the determinants of the lending interest rate of commercial banks ranged between studies that dealt with one group of determinants, some of which dealt with two groups and some other dealt with three groups. Some of these studies follow. Mbowe et al. (2020) conducted a study in Tanzania investigating the determinants of bank (LIR) for the period 2001-2017, the fixed effects model results showed a significant positive effect of the operating cost, deposits interest rate and non-performing loans on lending interest rate, and a negative effect of the size of the bank and inflation effects on lending interest rate. Asamoah and Adu. (2016) presented an empirical analysis of the determinants of the bank (LIR) in Ghana for the period 1970-2013. The study showed that the nominal exchange rate and the monetary policy rate have a significant positive impact on the interest rate of bank lending. While the fiscal deficit, real GDP, and inflation have a negative impact. Ali et al. (2016) analyzed the effect of internal variables on the lending rates of commercial banks in Pakistan for the period 2007-2014. The results of the fixed effects model showed a significant positive effect of investment-to-assets ratio and liquidity ratio on the lending rates of commercial banks in Pakistan, a significant negative effect of the deposit-to-assets ratio and loan-to-assets ratio on lending rates, whereas capital adequacy, management efficiency and asset quality do not have a significant impact on lending rates. Bhattarai (2015) investigated the lending interest rate determinants for six commercial banks in Nepal. Panel data analysis was used for the period 20102015. The results of the fixed effects model concluded that the ratio of operating cost to assets, return on assets, and risk of default have a significant positive impact, while the deposits interest rates have an insignificant positive impact. Kanwal (2014) studied the determinants of the interest rate in Pakistan, the study analyzed monthly data for the period 2005-2010. The results of the ordinary least squares showed that the inflation rate and the exchange rate have a positive significant effect on the interest 
rate in Pakistan. Georgievska et al. (2011) test the determinants of the lending rate in Greece for the period 2001-2009. The results of the Panel data analysis showed that lending rates are greatly affected by bank size and concentration, while less affected by non-performing loans and deposit rates. Georgievska et al. (2010) examined the determinants of lending interest rate and the interest rate spread of commercial banks in Macedonia for the period 2001-2009. The fixed effects model results indicating that the size of the bank and the capital adequacy have a negative and significant effect on the lending interest rates, while the deposits interest rate, non-performing loans, liquidity and return on assets have a positive and significant effect. The above studies dealt with the determinants of lending rates for (CB) in many countries, some of which focused on macroeconomic variables, others focused on bank characteristics and others dealt with macroeconomic variables and bank characteristics as determinants of commercial banks. The number of studies that have addressed this issue, despite its importance, is still few. In addition, no study has been conducted that examines the determinants of (LIR) in Jordan. Therefore, this study came to fill this gap and to provide empirical evidence from a developing country such as Jordan.

Based on the literature review, the study formulated the following null hypotheses:

$\mathrm{H}_{01}$ : There is no statistically significant effect of liquidity on the lending interest rate of the listed Jordanian commercial banks (JCB).

$\mathrm{H}_{02}$ : There is no statistically significant effect of profitability (ROA) on the lending interest rate of the listed (JCB).

$\mathrm{H}_{03}$ : There is no statistically significant effect of bank size on the lending interest rate of the listed (JCB).

$\mathrm{H}_{04}$ : There is no statistically significant effect of operating cost ratio on the lending interest rate of the listed (JCB).

$\mathrm{H}_{05}$ : There is no statistically significant effect of deposit interest rate on the lending interest rate of the listed (JCB).

$\mathrm{H}_{06}$ : There is no statistically significant effect of inflation on the lending interest rate of the listed (JCB).

\section{Data and Methodology}

\subsection{Data}

Annual data related to the following variables (lending interest rates, liquidity, bank size, profitability (ROA), operating cost, deposit interest rate) of the 13 (JCB) listed on the Amman Stock Exchange were collected from the Amman Stock Exchange database. Inflation data were collected from the Central Bank of Jordan database for the period 2011-2018. E Views 10 is used in analysis process.

\subsection{Methodology}

The current study aims to examine the determinants (Inflation, return on assets (ROA), liquidity, bank size, and operating cost ratio and deposit interest rate) of (LIR) of 13 Jordanian listed commercial banks for the period 2011-2018. The definition of the variables is listed in Table (1). This study relied in its methodology on the methodology of previous studies (Mbowe et al., 2020; Ali et al., 2016; Bhattarai, 2015, Georgievska et al., 2010) with some modifications to suit the objectives of the study. The study used the technique of Panel data analysis (pooled cross-sectional time series analysis). There are many benefits of using panel data these include the following: Controlling for individual heterogeneity, Panel data gives more useful data, more variability, less collinearity among the variables, more degrees of freedom and more efficiency. Panel data has the ability to identify and measure effects that are simply not noticeable in pure cross-section or pure time-series data (Baltagi, 2000). In order to estimate the determinants of lending interest rate of Jordanian listed commercial banks the following model is estimated:

$$
L I R_{i t}=\beta_{0}+\beta_{1} L I Q_{i t}+\beta_{2} R_{0 A}+\beta_{3 t} S_{Z I Z} E_{i t}+\beta_{4} O P C O S T_{i t}+\beta_{5} D E P O S R_{i t}+\beta_{6} I N F_{i t}+U_{i t}
$$

where: LIR, lending interest rate (dependent variable), Independent variables: LIQ, liquidity; ROA, return on assets; SIZE, bank size;OPCOST, operating cost; DEPOSR, deposit interest rate; INF, inflation rate. $\beta_{0}$, intercept. $\beta_{1}, \beta_{2}, \beta_{3}, \beta 4, \beta_{5}, \beta_{6}$, independent variables coefficient; $U$, error term. $i$, denote the cross-section from bank $1-13$; $t$, denote the time-series dimension ranging from 2011 - 2018.

\section{Table 1}

Study Variables Definitions

\begin{tabular}{ll}
\hline Dependent Variable & Definition \\
\hline Lending interest rate (LIR) & = Interest income on loans/Average Loans and advances \\
Independent Variables & $=$ Liquid asset / total asset \\
Liquidity Ratio (LIQ) & $=$ Net income / total assets \\
Profitability ratio (ROA) & $=$ Natural log of total assets \\
Bank size (SIZE) & $=$ Operating cost / total assets \\
Operating costs ratio (OPCOST) & $=$ Interest paid on deposit / deposits \\
Deposit interest rate (DEPOSR) & $=$ Percentage change in consumer price index \\
\hline
\end{tabular}




\section{Results and Discussion}

\subsection{Descriptive Statistics}

Descriptive analysis was used in this study to give a comprehensive description of the data used in this study by determining the minimum, maximum, mean, median and standard deviation of the study variables. Table 2 shows the results of the descriptive analysis of the dependent and independent variables of the 13 Jordanian commercial banks listed on the Amman Stock Exchange for the period 2011-2018.

Table 2

Results of the Descriptive Statistics

\begin{tabular}{|c|c|c|c|c|c|c|c|}
\hline & LIR & LIQ & ROA & SIZE & OPCOST & DEPOSR & INF \\
\hline Mean & 0.108949 & 0.093566 & 0.01211 & 9.353203 & 0.026296 & 0.033029 & 0.028212 \\
\hline Median & 0.105741 & 0.082852 & 0.012739 & 9.30722 & 0.02606 & 0.030404 & 0.03745 \\
\hline Maximum & 0.156636 & 0.225306 & 0.020466 & 10.41262 & 0.118344 & 0.040077 & 0.04775 \\
\hline Minimum & 0.084703 & 0.029939 & -0.00166 & 8.557473 & 0.006806 & 0.010675 & -0.00852 \\
\hline Std. Dev. & 0.01662 & 0.041007 & 0.004769 & 0.401996 & 0.011582 & 0.019043 & 0.021933 \\
\hline
\end{tabular}

For lending interest rate (LIR) the mean and median are $(0.108),(0.105)$ respectively. This means that Jordanian commercial banks charge an average of $10.8 \%$ annual interest on loans and advances. the maximum and minimum are (0.156), (0.084) respectively while standard deviation is (0.0166). This indicates that the minimum and average lending interest rates for Jordanian commercial banks are greater than the average lending interest rates between Jordanian banks (JODIBOR), which reached $(7.128 \%)$ in 2018 and $(6.88 \%)$ in (2017). For liquidity the minimum is $(0.029)$ while the maximum value is $(0.22)$. For ROA the minimum value is (-0.001), the maximum value is $(0.020)$. For bank SIZE the minimum value is (8.55) and the maximum value is (10.41). For OPCOST the minimum value is $(0.006)$ while the maximum value is $(0.118)$ and for DEPOSR the minimum value is $(0.010)$ and the maximum value is $(0.040)$ and the mean value is $(0.033)$. The inflation rate has been used to express the economic environment in Jordan. Table 2 shows that the value of the minimum inflation rate is (-0.021) while the value of the upper limit of inflation is (0.047).

\subsection{Correlation Matrix}

The correlation matrix between the independent variables of the study has been estimated to reveal whether there is a multicollinearity problem between the independent variables. This is because the existence of such a problem makes it difficult to measure the role of each independent variable in explaining the change in the value of the dependent variable. Gujarati (2003) recommended that if the correlation coefficient is less than 0.8 , then the variables do not suffer from the multicollinearity problem and are suitable for further statistical analysis. The results of the correlation matrix in Table 3 indicate that the highest correlation coefficient for the independent variables is between deposit interest rate and operating costs with a value of 0.55 which is less than 0.8 . Thus, there is no a multicollinearity problem between the study variables, so it is adopted for the current study.

Table 3

Correlation Matrix

\begin{tabular}{|c|c|c|c|c|c|c|c|}
\hline & LIR & LIQ & $\mathrm{ROA}$ & SIZE & OPCOST & DEPOSR & INF \\
\hline LIR & 1 & & & & & & \\
\hline LIQ & -0.01732 & 1 & & & & & \\
\hline ROA & 0.172861 & 0.201412 & 1 & & & & \\
\hline SIZE & -0.33491 & 0.25519 & 0.095966 & 1 & & & \\
\hline OPCOST & -0.0337 & 0.021641 & -0.10389 & -0.17419 & 1 & & \\
\hline DEPOSR & 0.216021 & -0.18408 & -0.20197 & -0.39947 & 0.552177 & 1 & \\
\hline INF & 0.258006 & 0.027659 & -0.01588 & -0.07561 & 0.079977 & 0.229808 & 1 \\
\hline
\end{tabular}

\subsection{Unit Root Test}

The time series stability test is one of the necessary requirements for choosing the appropriate econometrics model. There are many tests that are used in testing the unit root for panel data. The method by Levin, Lin and Chu test (LLC) has been chosen because it is one of the most used tests for testing the unit root for panel data. If the null hypothesis stating the existence of the unit root at the $5 \%$ level of significance is rejected, then the variable is stationary at the level, but if the null hypothesis is accepted, thus the variable is not stable at the level and the first difference must be taken and here it is necessary to test the existence of co-integration between study variables. Table 4 shows the (LLC) unit root test results, which indicate that all the study variables are stationary at level. Therefore, there is no need to test the co-integration probability of the study variables 
Levin, Lin \& Chu test Results

\begin{tabular}{|c|c|c|c|c|}
\hline Variable & LLC Statistics & Probability & Level of Integration & Stationary \\
\hline LIR & -16.3505 & 0.0000 & $\mathrm{I}(0)$ & Stationary \\
\hline LIQ & -12.5319 & 0.0000 & $\mathrm{I}(0)$ & Stationary \\
\hline ROA & -2.28575 & 0.0111 & $\mathrm{I}(0)$ & Stationary \\
\hline SIZE & -3.44587 & 0.0003 & $\mathrm{I}(0)$ & Stationary \\
\hline OPCOST & -6.11771 & 0.0000 & $\mathrm{I}(0)$ & Stationary \\
\hline DEPOSR & -54.4425 & 0.0000 & $\mathrm{I}(0)$ & Stationary \\
\hline INF & -9.13051 & 0.0000 & $\mathrm{I}(0)$ & Stationary \\
\hline
\end{tabular}

\subsection{Results and Discussion}

According to Green (2007) models that can be used to estimate panel data are pooled OLS, Fixed effects model and random effects model. Onuonga (2014) affirms that if the individual non-observable effects of the bank are not completely different then the pooled ordinary least square method is the simplest and most effective method of estimating panel data. While Cottrell and Lucchetti (2017) see that pooled OLS is unlikely to be appropriate in most cases.

In panel data analysis the Breusch-Pagan Lagrange Multiplier (LM test) is used to choose between pooled OLS and random effects models, while The Hausman test is used to choose between fixed effects model and random effects model (Baltagi, 2008).

The result of Breusch -Pagan Lagrange Multiplier test indicates that the Random effects model is chosen since the cross section Chi-Square is (26.03622) with probability of (0.0000), Time, Chi-Square is (12.93584) with probability of (0.0003), Both, Chi -Square is (38.97205) with probability of (0.0000). The result of the Hausman test indicates that the fixed effects model is preferred since the Chi-Square value is (20.06969) with probability of (0.0101). Table 5 shows the results of the fixed effects model, in addition to the inclusion of the values of Hausman test. The results in Table 5 shows that liquidity (LIQ) has a negative insignificant impact on lending interest rate of the listed Jordanian commercial banks. The negative relationship between liquidity and the lending interest rate can be explained by the fact that banks with high liquid assets leads to a decrease in the liquidity risk of banks, and this leads to lower lending interest rates. This result is consistent with (Georgievska et al., 2010) and inconsistent with (Cihak, 2004).

The results of the fixed effects model show that (ROA) has a significant negative impact on (LIR) with coefficient of (-0.714827) at significance level of $5 \%$. This is because the high profitability of banks helps them provide loans at low interest rates. As it has been realized that during economic prosperity, demand for borrowing increases, and the profits of different sectors increase, which leads to more profitable loans, and encourages the expansion of credit while reducing the lending interest rates. In the same context Windmeijer (2005) wrote that in economic expansion, the demand of business enterprises to borrow increases, profitable bank loans increase, the credit environment expands and competition increases between banks as banks tend to provide loans at low interest rates. This result is inconsistent with the result of Mbowe et al. (2020).

The results of the fixed effects model also show that bank size (SIZE) has a negative significant impact on (LIR) of Jordanian listed commercial banks, with coefficient of (-0.05541) at significance level of $1 \%$. This is attributed to two major facts; on one hand, it is because large banks deal with credit risk with great ability, by setting up sound and effective credit risk management systems and better use of diversifying the credit portfolio. On the other hand, those large banks have economies of scale, which enables them to offer loans at lower interest rates than competitors. In the same context Georgievska, et al., (2010) stated that the size of the bank primarily reflects the economies of scale, and thus the higher volume of assets should contribute to lower lending rates. In this regard, Atakelt and Veni, (2015) wrote, large banks enjoy a competitive advantage in economies of scale, and as a result they offer loans to their clients at low interest rates. This result is in line with the findings of (Mbowe et al., 2020; Cihak, 2004).

As for the operational cost (OPCOST), the results of the analysis show that it has a positive and insignificant effect on the (LIR). The positive relationship can be explained by the fact that commercial banks transfer these costs directly to customers, in the same context Karanu and Ireri, (2015) wrote that the increase in the various operating costs of banks contributes to the increase in lending rates. This result is consistent with a finding of (Mbowe et al., 2020; Bhattarai, 2015).

The results of deposit interest rate (DEPOSR) show a positive and significant effect on the (LIR) of (JCB), with a coefficient value (1.440586) at a significance level of (1\%). This falls on the fact that the increase in the interest paid on customer deposits increases the (LIR) of commercial banks, this result is in line with the loanable funds theory, which considers that there is a positive relationship between the (LIR) and the deposits interest rate, as the bank transfers the cost of funds to borrowers, In this context, Nasrin et al.(2015) he wrote that increasing interest on deposits in the short term increases banks 'costs for funds, which leads to an increase in interest on loans. This result agrees with the results of (Mbowe, et al., 2020; Bhattarai, 2015). 
For inflation (INF) the findings of the fixed effects model in Table (5) show a positive and significant effect of inflation on (LIR) of listed Jordanian commercial banks with coefficient value (0.17094) at significance level of (1\%). This is explained with the fact that the increase in inflation rates prompts commercial banks to raise the (LIR) on loans granted to clients to preserve the real interest, leading to an increase in the (LIR) of commercial banks, in the same context Kari (2007) wrote that the increase in inflation rates lead banks to increase their lending rates to preserve space with inflation. This result is consistent with results of (Mbowe et al., 2020; Bhattarai, 2015; Cihak, 2004; Hsiao, 1986) but not consistent with the result of (Ali et al., 2016).

Table 5

Fixed Effect Model Results

\begin{tabular}{|c|c|c|c|c|c|}
\hline \multicolumn{6}{|l|}{ Dependent Variable: LIR } \\
\hline Variable & Coefficient & Std. Error & t-Statistic & & \\
\hline $\mathrm{C}$ & 0.581464 & 0.133422 & & 4.358077 & 0 \\
\hline LIQ & -0.00582 & 0.036916 & & -0.15755 & 0.8753 \\
\hline $\mathrm{ROA}$ & -0.714827 & 0.295262 & & -2.42099 & 0.018 \\
\hline SIZE & -0.05541 & 0.013531 & & -4.09532 & 0.0001 \\
\hline OPCOST & 0.06232 & 0.284752 & & 0.21887 & 0.8274 \\
\hline DEPOSR & 1.440586 & 0.170189 & & 8.464621 & 0.0000 \\
\hline INF & 0.17094 & 0.041083 & & 4.1609 & 0.0001 \\
\hline R-squared & 0.828217 & Hausman Test & & & \\
\hline Adjusted R-squared & 0.785271 & Chi-Square & & & 20.06969 \\
\hline S.E. of regression & 0.009791 & Probability & & & 0.0101 \\
\hline F-statistic & 19.28514 & & & & \\
\hline Prob(F-statistic) & 0.0000 & & & & \\
\hline
\end{tabular}

The value of the adjusted R-Square is $(0.785271)$ which indicates that the independent variables in the econometrics model explain $78 \%$ of the change in the lending rate of Jordanian commercial banks.

\subsection{Diagnostic Tests}

To ensure that the model meets the requirements of a good regression model, its reliability has been tested. The results of the diagnostic tests in the Tables $(6,7,8)$ indicate that the level of significance of the three tests is greater than $5 \%$, and this proves the model is good.

Table 6

Breusch-Godfrey Serial Correlation LM Test

\begin{tabular}{llll}
\hline F-statistic & 2.721175 & Prob. & 0.1082 \\
Obs*R-squared & 4.036514 & Prob. Chi-Square & 0.1201 \\
\hline
\end{tabular}

Table 7

Heteroskedasticity Test: Breusch-Pagan-Godfrey

\begin{tabular}{lrrr}
\hline F-statistic & 1.319829 & Prob. F & 0.0876 \\
Obs*R-squared & 10.58839 & Prob. Chi-Square & 0.0982 \\
\hline
\end{tabular}

\section{Table 8}

Normality Test

$\begin{array}{ll}\text { Jarque-Pera } & 0.494434 \\ \text { Probability } & 0.780971\end{array}$

\section{Conclusions}

This study aimed to examine the determinants of lending interest rates for Jordanian commercial banks listed on the Amman Stock Exchange for the period 2011-2018. The study used panel data (time series-cross sectional data) analysis. The fixed effects model is performed as suggested by Hausman test to estimate the impact of liquidity, (ROA), bank size, operating cost, deposit interest rate and inflation on lending interest rate. The results of the fixed effects model revealed that the profitability of the bank measured by the (ROA) and the size of the bank have a negative and significant impact on the (LIR) of (JCB). Increasing the bank's profitability enables the bank to provide credit facilities at low interest rates, as it can compensate for this decline in 
lending rates through the expansion of lending. There is some correlation between the size of the bank and lending interest rates; as the increase in the size of the bank helps the bank to offer low lending interest rates due to its great ability to deal with credit risks in addition to its enjoyment of economies of scale that make it offer low lending interest rates compared to competitors.

The results of the analysis also showed that the deposits interest rate and inflation have a positive and significant effect on the (LIR) of (JCB). The increase in the deposit interest rate increases the lending interest rate for the bank, since the bank transfers the cost of funds (deposit interest rate) for borrowers. The increase in inflation contributes to the increase of the bank's (LIR), as the bank seeks to maintain the same levels of real interest it charges by transferring the inflation rate for borrowers.

The results showed that liquidity has a negative relationship with the (LIR), which means that banks with high liquidity have low (LIR). While the results showed that the operating cost has a positive relationship with the (LIR), this means that the banks that have high operating costs have high (LIR).

The study suggests that banks should use (ROA) and the size of the bank as tools to reduce the (LIR), as it is one of the factors that can cause a further decrease in the (LIR). Also, the study suggests directing (JCB) to merge with each other to form largesized banks that increase their competitiveness and thus contribute to reducing the (LIR). The study also suggests commercial bank departments to reduce the deposit interest rate to reduce the (LIR), since the results show that the deposit interest rate has

the most effect on raising the (LIR). The study also proposes a partial transfer of inflation to borrowers to ensure low rates of lending interest for Jordanian commercial banks.

\section{References}

Ali, Z., Bashir, Z., Arshad, M. U., Ghazali, A., Asif, M., \& Khan, F. N. (2017). Analysis of Some Inner Factors Affecting the Lending Rate and Commercial Bank Behavior:(An Empirical Study Based on the Commercial Banking Sector of Pakistan). e-Finanse, 12(4), 111-119.

Andrew, F. (2004). Credit Risk Management Essential Capital Markets.

Asamoah, L. A., \& Adu, G. (2016). An empirical analysis of the determinants of interest rates in Ghana. Journal of African Business, 17(3), 377-396.

Atakelt, H., \& Veni, P. (2015) Determinants of credit risk in Ethiopian private commercial banks. International Journal of Accounting and Financial Management Research, 5(3), 1-14.

Baltagi, B. (2008). Econometric Analysis of Panel Data. John Wiley \& Sons.

Baltagi, B. H. (2000). Econometric analysis of panel data. $2^{\text {nd }}$ ed., New York: John Wiley \& Sons.

Bhattarai, Y.R. (2015). Determinants of lending interest rates of Nepalese commercial banks. Economic Journal of Development $19 \& 20(1-2), 39-59$.

Cihak, M. (2004). The Determinants of Lending Rates and Domestic Spreads in Croatia, In Republic of Croatia: Selected Issues and Statistical Appendix; IMF CountryReport No. 04/251.

Cottrell, A., \& Lucchetti, R. J. (2017). Gretl user's guide: gnu regression, econometrics and time-series library. Available at http://www.gnu.org/licenses/fdl.html

Crowley, J. (2007). Interest Rate Spreads in English-Speaking Africa. IMF Working Paper. April 2007, 123-45.

Friedman, B. M., \& Kuttner, K. N. (1991). Why Does the Paper-Bill Spread Predict Real Economic Activity? Cambridge, MA: National Bureau of Economic Research. https://doi.org/10.3386/w3879

Georgievska, L., Kabashi, R., Manova-Trajkovska, N., Mitreska, A., \& Vaskov, M. (2011). Determinants of lending interest rates and interest rate spreads. Special Conference Paper, Bank of Greece.

Gujarati, D. N. (2003). Basic Econometrics. McGraw-Hill. New York.

Hsiao, C. (1986). Analysis of panel data. Cambridge University Press. Cambrige. U.K.

Keynes, J. M. (1936). The General Theory of Employment, Interest, and Money. Macmillan, London.

Kanwal, K. (2014). Determinants of Interest Rate: Empirical Evidence from Pakistan. Journal of Economics and Sustainable Development, 5(13), 25-30. https://www.researchgate.net/publication/287996526.

Karanu, E. \& Ireri J. (2015). Effects of operational cost on lending interest rates of commercial banks in Kenya. Journal of Business, Economics and Finance, 4(3), 363-373. DOI: 10.17261/Pressacademia.2015313058

Kari, H. (2007). Determinants of Commercial Banks Interest Rate Spreads: Some Empirical Evidence from the Eastern Caribbean Currency Union, Working Papers, (WP/07/01) Eastern Caribbean Central Bank (ECCB).

Mbowe, W., Mrema, A., \& Shayo, S. (2020). Determinants of bank lending interest rates in Tanzania. American Journal of Industrial and Business Management, 10, 1206-1236. DOI: 10.4236/ajibm.2020.107081.

Nasrin, S., Momtaz, M., Saha, M., Das, B. \& Younus, S. (2015). Lending rates behavior in Bangladesh: Some facts and determinants," Working Papers id: 8037, e- SocialSciences.

Olusanya, S.O., Oyeboafee S., \& Ohadebere E.C. (2012). Determinants of lending behavior of commercial banks: evidence from Nigeria, a co-integration analysis. Journal of Humanities and Social Science, 5(5),71-80. http://www.iosrjournals.org/iosr-jhss/papers/Vol5-issue5/G0557180.pdf. 
Onuonga, S.M. (2014). The analysis of profitability of Kenya's top six commercial banks: internal factor analysis. American International Journal of Social Science, 3(5), 94-103.

Peng, W. S., Lai, K., Leung, F., \& Shu, C. (2002). Impact of Interest Rate Spread Rate Shocks on the Performance of Banking Sector. Hong Kong: Hong Kong Monetary Authority.

Ramakrishnan, G., \& Thakor, E. (2000). Measuring the efficiency of decision making units. European Journal of Operational Research, 2(6), 429-44.

Rose, P.S. (2003). The determinants of interest rates: Competing ideas. In Capital markets: Financial institutions and instruments in a global marketplace (8thed.).McGraw Hill/Irwin.

Sheriff, I. M. \& Amoako, G. K. (2014). Macroeconomic determinants of interest rate spread in Ghana: Evidence from ARDL modeling approach. Journal of Finance and Bank Management, 2(2), 115-132.

Windmeijer, F, (2005). A finite sample correction for the variance of linear efficient two- step GMM estimators. Journal of Econometrics, 126(1), 25-51.

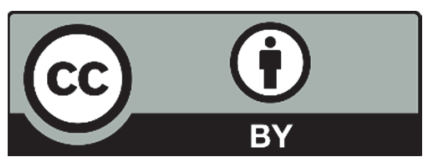

(C) 2021 by the authors; licensee Growing Science, Canada. This is an open access article distributed under the terms and conditions of the Creative Commons Attribution (CC-BY) license (http://creativecommons.org/licenses/by/4.0/). 